\title{
Study on Circular Economy Education in Rural Areas in China
}

\author{
Ping Guo \\ School of Economy and Management, \\ Shijiazhuang Tiedao University \\ Shijiazhuang, China \\ guo_gp@163.com
}

\author{
Xinning Zhang \\ School of Economy and Management, \\ Shijiazhuang Tiedao University \\ Shijiazhuang, China \\ zhxn@sohu.com
}

\begin{abstract}
As we all know, the development of circular economy in Chinese rural area can't do without farmer's participation, but at the present general farmers understand very little to circular economy, and the participation level is very low. Therefore it needs to carry on education to farmers, which can speed up the building of circular economy in the countryside. This paper analyses the behavior of farmer participation in the circular economy currently, and puts forward several kinds of models, at last proposes implementation problems that need attention.
\end{abstract}

Keywords-education;farmer;circular area;model

economy;rural

\section{INTRODUCTION}

Along with the economical development, the environmental pollution which brought by the industrialization has had the huge destructive effect to the ecosystem and the society. ${ }^{[1]}$ After weighting these four aspects of economic development, population growth, resources consumption and environmental protection, the people proposed the circular economic system thought. Now the Chinese government takes the development of circular economy so seriously. the State Council issued "The certain Opinions on Speeding up the Circular economy Development" for several years, and established the guiding principle, the basic principle and essential target for the development of circular economy, proposed explicitly the strengthening the macroscopic instruction and establishing the promotion policy mechanism for the circular economy development. And the "Circular economy Law Revision Draft" has been proposed to the Standing Committee of the National People's Congress to consider. Obviously, the circular economy has already been integrated in the mainstream economic ideals in China, and at the future it will has the profound influence. ${ }^{[2]}$

However, now the key target of circular economic development in China is mainly the industry and the Key enterprise. ${ }^{[3]}$ The projects of agricultural and the circulation economic development in rural area, as the whole, have been suspended in the comparatively secondary position. At present the sustainable development consciousness was quite still weak in rural area, and the behaviors of participation circular society construction are few, and the ability of it is weak. ${ }^{[4]}$ This situation has formed the barrier to a certain extent to the circular economic development in the countryside.

\section{THE PRESENT SITUATION OF FARMERS PARTICIPATING IN CIRCULAR ECONOMIC DEVELOPMENT IN RURAL AREA}

\section{A. Lack of Understanding to The Circular economy}

Although some people have understood the sustainable development and the environmental protection to a certain degree, but actually they know very little to the rural circular economy, and the concept of rural circular economy to most farmers is the new term which have never heard of before, not to mention the participation in the construction of rural circular society. Speaking of the environmental awareness, the people who have the shallow consciousness, namely realizing the risk of environmental pollution and the resources exhausted are still few. And ones who have in-depth consciousness of maintaining the way of sustainable development and rural circular community, and through the values transformation changing production method and the life style are even few.

\section{B. Low Degree of Farmer's Involvement in Rural Circular Eeconomy}

Because farmers think that the social decision-making is government's matter, has nothing to do with oneself, thus they already cannot participate in the decision-making positively, also cannot form the formidable surveillance strength. These formed the cultural barrier for public to participate in the rural circular economy. But speaking of the farmer who has the sustainable development consciousness, the current important matter that must be faced now is lacking the Social organizations. For social public are many broad, and the structure is loose, and the knowledge level and quality is different, so it is very difficult to organize effectively the public, and to synthesize the numerous individual viewpoint to the reasonable farmer wish, and to express by the effective form, as well as to uniform the direction of each farmer participation, thus to display function in rural economy development. ${ }^{[5]}$ Although in the current this work had certain result, but there are still many questions. Moreover, even if the farmer participated in some activities, also only pauses in individual and clique's participation level. 


\section{Lack of the Effective Mechanism of Farmer Participation}

Although the basic principle of farmer involvement in policy-making and inspection has already been established, but the mechanism of farmer participation has not realized the legalization, and also lacks the concrete implementation means in the laws and regulations and the decision-making procedure of farmer participation. In the scope of farmer participation, now farmers only participate in certain concrete and the partial related motions, they cannot have powerful function in the aspect of social decision-making and social surveillance. For example, in the environmental protection aspect, the people often protest or carry on stops to certain serious pollution or ecological environment destruction that has been exist, this is belong to the passive participation. While the rural circular economy requests the farmer to carry on "the plan participation" and "the process participation" before constructing the rural circular economic society and the environmental pollution and the destruction.

\section{THE QUESTION-POSED OF CIRCULAR ECONOMY EDUCATION IN THE DEVELOPMENT OF RURAL CIRCULAR ECONOMY}

In the most rural areas, because the economy is not developing, and the living standard is low, the people's most important matter concerned is to meet the basic life need, and the environment quality may ignore, therefore their environmental awareness is lighter. ${ }^{[6]}$

Farmer's sustainable development consciousness is deciding the degree of participation to the rural circular economy. Therefore, to promote farmer's participation may be from raising farmer's sustainable development consciousness. As to China, the frail ecological environment and the resources system support the traditional strategy for a long time with difficulty. Therefore, the time has not permitted the production and the enhancement of farmer's sustainable development consciousness experiences a long natural evolution process. The government must take the measure, from the top to bottom, through the external education, to enhance the rural area 's sustainable development consciousness fast, and to mobilize farmers to participate in the construction of CIRCULAR society.

\section{THE MODEL ANALYSIS OF CIRCULAR ECONOMY EDUCATION IN RURAL CIRCULAR ECONOMY DEVELOPMENT}

\section{A. The Elementary Education Mode}

The developed country takes seriously to the environmental education for the whole people. ${ }^{[7]}$ As early as in 1970, the US passed "Environment Educational Law", implements the environmental education beginning from the elementary school, and almost all universities in US, Canada, Britain and so on, have environment related courses. But in China, although the State Educational Committee has organized the personnel to increase the content related to the population, the resources, the environment and the sustainable development in 《Nature $\rangle$ in the elementary school teaching material and the 《Geography》 in the middle school teaching material, but generally speaking, the sustainable development thought has not yet systematically passed through the entire compulsory education system, and the rural circular economy's thought has not been included in the education content. Therefore we suggested that the rural circular economical content, the sustainable development, and the environmental protection integrates in the elementary and middle schools curriculum, and to make concrete application which has the actual operation significance to elementary and middle school students' daily behavior standards in the education, and to cultivate fine environmental ethics and codes of conduct.

\section{B. The Popular Education Mode}

While to strengthen the regular school education, it needs to foster the universal rural circular economy consciousness for the whole farmers. This asks mass media and the Community organizations according to the different level of farmer's characteristic to develop the spirited propaganda and various training. ${ }^{[8]}$ Through the establishment of consultation organization and the populace information network, farmers can obtain the information of the rural circular economy promptly, then can participate in the decision-making and the monitor procedure. The government should regularly notify farmers the advanced experience, the environment quality condition, the pollution and ecological damage work, as well as government's environmental protection work, and rural CIRCULAR economic development in the rural circular economy demonstration areas, so to enhances the transparency of the government administration and the policy-making. ${ }^{[9]}$

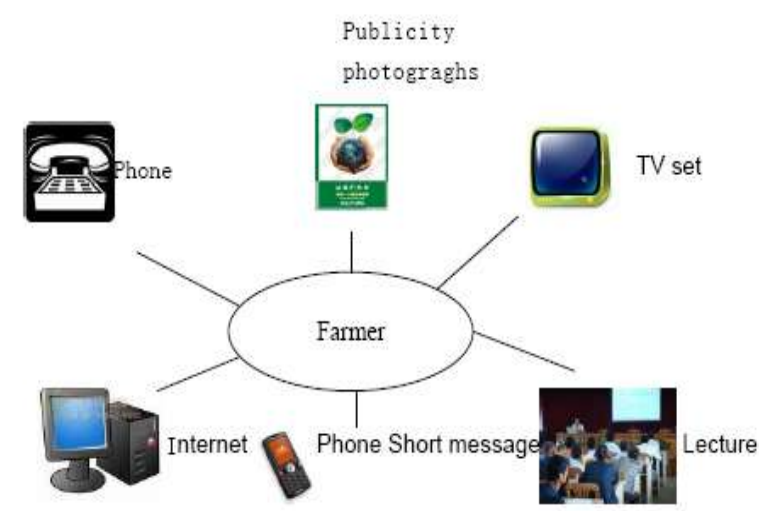

Figure 1. The popular education pattern

\section{The Enterprise Order Form Education Mode}

In the agricultural circular economical industry chain, leading enterprise founds the education training organization, connects the science and technology and market, and invites the expert to train the farmer. On the one hand the leading enterprise enhance its independent innovation ability, on the other hand satisfy the market demand. The product's added value of enterprise intensive processing is high, and farmers providing raw material to the enterprise have the enthusiasm, simultaneously the local resources have the condition as the enterprise raw material supply base. In the foundation of training the 
demonstrative peasant households, by setting examples, the contract planting, the order form purchase and lowest subsidy price purchase, thus, the expert, the enterprise, and the peasant household can join in together, and carry on the agricultural circular economical industry chain's construction. ${ }^{[10]}$

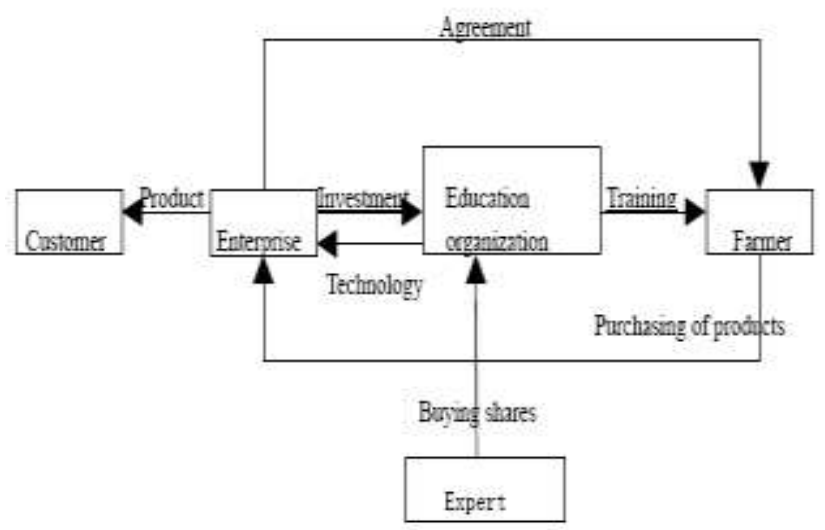

Figure 2. The enterprise order form education pattern

\section{The Association Education Mode}

The folk association organization may help the farmer to carry on the production way and the life style of the circular economy which is less investment and high output. In China, this kind of civic body is quite limited on scale, quantity, and its function. The government should affirm and provide the folk organizations participating in environmental protection and the work of promoting the rural circular economy, and give supports positively for the essential manpower, the physical resource, the technology and the financial support. ${ }^{[11]}$

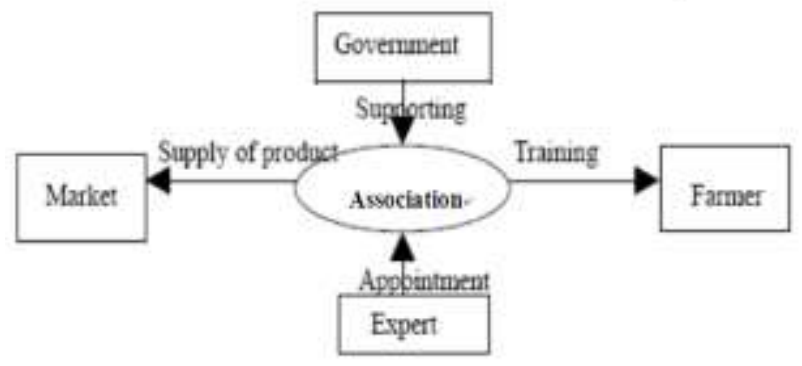

Figure 3. The association education pattern

\section{E. The Project Education Mode}

In the area of fruitful ecology resources, to unify the local resources superiority, the government should advance the ecological agriculture county construction vigorously, implement the comprehensively "the clean countryside, the clean water source, the clean homestead" project, develop reasonably and protect the agricultural natural resource, help the farmer start undertaking, and train some related. For example, encouraging the eco-tourism service items, to satisfy the city people to return the nature, and taking the sightseeing agriculture as the important content in the agricultural modern service industry, to further increase the farmers' income.

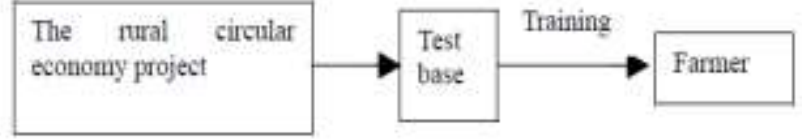

Figure 4. The project education pattern

\section{IMPLEMENTATION RECOMMENDATIONS}

\section{A. Sufficient Fund Guarantee for Farmer Education}

Practice proves that the financial funds use in the farmer education, comparing to use in some other project investment in the countryside has the more actual effect, and the latent benefit is bigger. The government should have strong support and make the stable investment, at the same time, utilize methods positively of finance, credit, and tax revenue, encourage the enterprise, farmer and the social civil organization participating in the farmer education, establishes the multiplex investment system. ${ }^{[12]}$

Also government departments should attach great importance to the improvement of the ecological awareness for farmers and the protection of rural areas, input construction of the appropriate environmental infrastructure, such as waste disposal facilities, and increase the environmental management system in the region, strengthen the supervision of the ecological environment, and effectively enhance farmers' self ecological awareness.

\section{B. Farmer Education Plan Conforming to Local Ecological Environment}

Before carrying on the local farmer's education work the training organization may make some investigations. The investigations can be carried on the local resources characteristic, financial circumstance development existing condition and so on, then the rural circular economy education plan can be worked out according to the local ecological environment.

Circular economy education firstly need to eliminate the farmers ideological concerns that Doing environmental protection will reduce the economic income, to actively meet the new demands of life of city dwellers for being in pursuit of environmental protection life, and vigorously promote the unique advantages of ecological agriculture; advocacy that developing ecological agriculture is the optimal way to increase income, and is the best choice to ensure the sustainable development of the agricultural economy. Circular economy education also need to provide guidance of environmental technologies and services, and to guide farmers to develop ecological agriculture economy, to develop environment-friendly agriculture brand, and to develop ecological agriculture products supply market, then supporting circular economy agriculture development. In addition, circular economy education require to strengthen the science and technology, agricultural training, and actively help solve problems and difficulties encountered in local rural production. By creating environmentally friendly industries, increasing farmers' income, farmers recognize the important value of 
the natural environment, and to protect, develop, and utilize the rural environment.

\section{Taking Flexible Effective Education Method}

Agricultural production is very practical, so in the teaching way we advocate the brief classroom teachers, but carrying on the scene teaching, the field place teaching, the simulation scene teaching, the skill operation teaching, the case discussion teaching and so on with the massive class hours and the energy. By using the form that farmers are easy to understand and study to enhance the enthusiasm for farmer to participate in education, this will have the actual effect. Moreover, we may carry out the modern longdistance agricultural education, such as broadcast, television, video recording etc, if the condition permission, we may using the computer network technology, the satellite transmission technology and so on.

\section{Establishment of a Sound Environmental Laws and Regulations}

The current environmental legal system of pollution prevention in rural areas is lack of appropriate regulations for pesticides, fertilizers, livestock and others easy to have pollution, a large number of farmers in the use of such products without legal constraint, resulting in destruction of the ecological environment. Related departments should establish and improve rural laws and regulations on the circular economy or the ecological environment, and to ensure the sustainable development of rural circular economy environment.

\section{ACKNOWLEDGEMENT}

The paper is the part research results of project "Study on Coordinated Development of Poverty Alleviation and Ecological protection in the Rural Areas around central capital(Item Number: HB13JJ023)", which accepted the fund of 2013 Social Science Project in Hebei Province in China.

\section{REFERENCES}

[1] Taguchi Taro, "Development of education program for human support in rural area - Education Program for "shuraku Shiennin" and "chiiki Okoshi Kyoryokutai", AIJ Journal of Technology and Design, v 19, n 42, Jun. 2013, pp. 719-724, Language: Japanese, Architectural Institute of Japan, doi: 10.3130/aijt.19.719.

[2] Guo Ping, "The Construction on Information Service System in Recycling Economy" Proc. the 1st International Workshop on Education Technology and Computer Science(ETCS 2009), Inst. of
Elec. and Elec. Eng. Computer Society, 2009,v 3, pp. 391-394, IEEE Computer Society, doi: 10.1109/ETCS.2009.615.

[3] Yu Jiao Long, "How to promote employment by developing recycle economy", Advanced Materials Research, v 219-220, pp. 327-330, 2011, Advanced Research on Information Science, Automation and Material System, Trans Tech Publications, doi: 10.4028/www.scientific.net/AMR.219-220.327.

[4] Zhi Li, "On the establishment of ecological circular economy under the guidance of sustainable development concept", Advanced Materials Research, v 524-527, pp. 3647-3650, 2012 Natural Resources and Sustainable Development II, Trans Tech Publications, doi: 10.4028/www.scientific.net/AMR.524-527.3647.

[5] Ma Wenlin, Ma Chao,Liu Jianwei, "Transformation of Chinese agricultural economy to low carbon under guidance of circular economy", Proc. 2010 International Conference on E-Product EService and E-Entertainment(ICEEE2010), IEEE Computer Society, doi: 10.1109/ICEEE.2010.5660650.

[6] Hao Jingya, Zhu Fuxing, "The analysis of developing mode of rural clean energy: Using Xuzhou as an example", Proc. Communications in Computer and Information Science(ISAEBD 2011), v 210 CCIS, n PART 3, pp. 220-226, 2011, Springer Verlag, doi: 10.1007/978-3-642-23065-3_33

[7] He Hong S, Lewis Bernard J. , Baer Adam D. , and Nigh Timothy A. , "Exploring linkages between people and rural landscapes at broad ecological scales" Landscape and Urban Planning, v 97, n 1, Jul. 2010, pp. 49-57, Elsevier, doi: 10.1016/j.landurbplan.2010.04.011.

[8] Zhu Jingdong, Zhou Zhen, "Continuing education and training of teachers in rural areas based on mobile learning and mobile services", Proc. 2009 1st International Conference on Information Science and Engineering(ICISE 2009), pp. 3273-3275, IEEE Computer Society, doi: 10.1109/ICISE.2009.428.

[9] Wei Dongling, Liu Shouyi, Liu Jiajun, "Network information impacting on rural education" Proc. 2012 International Conference on Computer Science and Information Processing(CSIP 2012), pp. 918-921, IEEE Computer Society, doi: 10.1109/CSIP.2012.6309004.

[10] Kim Jin-Young, "Development of agricultural cooperatives for revitalization of the rural community - focused on the case study of 'Sunkist"', International Journal of Smart Home, v 7, n 3, 2013, pp. 293-299, Science and Engineering Research Support Society, ISSN: 19754094

[11] Adinarayana J. Azmi S. , Tewari G. , and Sudharsan, D., "GramyaVikas: A distributed collaboration model for rural development planning", Computers and Electronics in Agriculture, $\mathrm{v}$ 62, n 2, Jul. 2008, pp. 128-140, Elsevier, doi: 10.1016/j.compag.2007.12.008.

[12] Bo Zhou, "Generality of the strategies promoting the overall development of urban and rural education in all government", Proc. 2011 International Conference on Electrical and Control Engineering(ICECE 2011) pp. 5941-5943, IEEE Computer Society, doi: 10.1109/ICECENG.2011.6057579. 